\title{
OUTCOME OF OPEN PYELOPLASTY ON IPSILATERAL RENAL FUNCTION
}

\author{
HAMUDUR RAHMAN ${ }^{1}$, MD SAYEDUL ISLAM ${ }^{2}$, MD. GOLAM MOWLA CHOWDHURY ${ }^{2}$, AKM ANWARUL \\ ISLAM $^{2}$, ISTEAQ AHMED SHAMEEM ${ }^{2}$
}

${ }^{1} 250$ bedded TB Hospital, Shaymoli, Dhaka, ${ }^{2}$ Department of Urology, Bangabandhu Sheikh Mujib Medical University

\begin{abstract}
Objective: The objective of this study is to determine the ipsilateral renal function after open pyeloplasty.

Patients and methods: The study comprises 50 patients with ultrasonographically and urographically demonstrated hydronephrosis and primary pelvi-ureteric junction obstruction for reconstructive surgical treatment at urology department of Bangabandhu Sheikh Mujib Medical University Hospital between January 2012 and September 2013. AndersonHynes pyeloplasties were performed in 50 patients. Data were collected by interview, review of records and documents in data collection sheet. Data were analyzed by using paired $t$-test. Level of significance was set at $5 \%(P<0.05)$. Statistical analysis done by SPSS (SPSS Inc. Chicago, IL, USA), version 16.0.0.

Results: The male and female ratio was1: 0.33. Mean age of the patients was 7.35 years. Left and right side ratio was 1.5: 1 . The mean \pm SD of pre operative cortical thickness was $3.67 \pm 0.91$ and post operative thickness after 1 month, 3 months, 6 months and 12 months were $3.95 \pm 0.91,4.61 \pm 1.18,4.61 \pm 1.18,5.15 \pm 1.31$ and $6.22 \pm 1.37$ respectively. The mean $\pm S D$ of split renal function were $24.22 \pm 3.42$ and $29.14 \pm 4.20$ in pre operative and post operative respectively. The mean \pm SD of split GFR were $25.38 \pm 4.11$ and 34.47 \pm 6.30 in pre operative and post operative respectively. Renal functional status was seen as improvement in 39, stable in 3, and deterioration in 2 patients.
\end{abstract}

Conclusions: When dealing with patients with pelviureteric junction obstruction, surgical treatment should be undertaken in patients with symptoms and/or impaired renal function.

Key words: Pyeloplasty, Ipsilateral renal function, Outcome.

Bangladesh J. Urol. 2015; 18(1): 28-32

\section{Introduction}

Uretero-pelvic junction obstruction is the most common form of obstruction in the upper urinary tract. Although the malformation is believed to be congenital, its actual dysfunction may manifest at any time from intrauterine life to old age[1]. It is reported to occur in 1: 500 to 1:1250 live births[2]. The uretero-pelvic junction obstruction does not represent a single anatomic entity but rather a set of obstructive process that result from multiple etiologic factors. Causes of obstruction are varied and include an aberrant lower pole crossing vessel, a large redundant pelvis, a thinned and narrowed ureteral Correspondences: Hamudur Rahman, 250 bedded TB Hospital, Shamoli, Dhaka. E-mail: drhamudurrahman@gmail.com segment, a high inserting ureter, a valve or an intrinsic defect at the uretero- pelvic junction and external compression[3]. Uretero-pelvic junction obstruction can be congenital or acquired as a result of some disease such as stone, urothelial tumors, or previous surgery. Neonates and infants usually present with palpable flank mass while older children and adults commonly present with intermittent flank or abdominal pain[4]. Stones may coexist with uretero-pelvic junction obstruction and indeed may be caused by uretero-pelvic junction stenosis; also stone itself may generate edema that may appear as uretero-pelvic junction obstruction that should be ruled out. Surgical repair is indicated by significantly impaired renal drainage or progressive 
deterioration of renal function. Other indications for active intervention are to relieve pain, or treat pathologies secondary to obstruction like calculi and infections ${ }^{2}$. All of these procedures involve reconstruction of the uretero-pelvic junction, elimination of other contributing factors such as redundant pelvis or crossing vessel and ascertainment of dependent drainage of the renal pelvis. Some authors have postulated that operative intervention will lead to an increase in renal function in half the cases, and a stationery state in the rest, whereas others have been unable to confirm this observation[5]. The aim of this study is to determine the renal function after open pyeloplasty.

\section{Patients and methods}

It was a hospital based prospective study conducted at urology department of Bangabandhu Sheikh Mujib Medical University from January 2012 to September 2013. Inclusion criteria were hydronephrosis due to pelviureteric junction obstruction with split renal function $<30 \%$ and unilateral involvement of the kidney. Exclusion criteria were refusal to take part in the study, hydronephrosis with hypertension, hydronephrosis with diabetes mellitus, secondary pelviureteric junction obstruction and bilateral involvement of the kidney. Fifty patients were selected according to inclusion and exclusion criteria. Data were collected by interview, review of records and documents in data collection sheet. The patients were evaluated by a standard investigation protocol consisting of ultrasonography, intravenous urography and renal scintigraphy, which were repeated postoperatively as scheduled. All patients were contacted over telephone as scheduled for follow up after pyeloplasty. Ethical clearance for the study taken from the Institute Review Board of Bangabandhu Sheikh Mujib Medical University. Written informed consent was taken. Statistical analysis done by SPSS (SPSS Inc. Chicago, IL, USA), version 16.0.0. Data were analyzed by using paired t-test. Level of significance was set at $5 \%(P<0.05)$.

\section{Results}

Fifty patients underwent preoperative evaluation regarding renal function, followed by Anderson-Hynes dismembered open pyeloplasty, and finally postoperative evaluation related to renal function. Six patients were lost to follow up. The study conducted to compare 44 patients renal function before and after open pyeloplasty. Male patients were predominant shown in table-I. Five or less than five years patients were more shown in table-II. Left kidneys were more affected shown in tableIII. Postoperative cortical thickness was gradually increased in most of the patients shown in table-IV. Split renal function and glomerular filtration rate improved after operation shown in table- $\mathrm{V}$. Thirty nine patients had improved renal function shown in table-VI. Quantitative improvement of renal function in each group shown in table-VII.

Table-I

Distribution of patients according to sex $(n=44)$

\begin{tabular}{lcc}
\hline Sex & No & Percentage \\
\hline Male & 33 & 75.0 \\
Female & 11 & 25.0 \\
\hline Total & 44 & 100.0 \\
\hline
\end{tabular}

Male: female $=1: 0.33$

Table I shows the distribution of patients according to sex. Male was predominant than female which was 33 (75.0\%) cases and $11(25.0 \%)$ cases respectively. The male and female ratio was $1: 0.33$.

Table-II

Distribution of the patients by age $(n=44)$

\begin{tabular}{lcc}
\hline Age (in year) & No & Percent \\
\hline$<5$ & 27 & 61.4 \\
$6-10$ & 10 & 22.7 \\
$>10$ & 7 & 15.9 \\
\hline Total & 44 & 100.0 \\
Mean \pm SD (Range) & $7.35 \pm 9.83$ & $(0.58-37)$ \\
\hline
\end{tabular}

Table II shows the age distribution of the patients. Out of all patients maximum $61.4 \%$ were belonged to d" 5 years age group followed by $22.7 \%$ within 6 to 10 years, and $15.9 \%$ above 10 years age group. Mean age of the patients was 7.35 years.

Table-III

Distribution of patients according to side ( $n=44)$

\begin{tabular}{lcc}
\hline Side & No & Percentage \\
\hline Left & 27 & 61.36 \\
Right & 17 & 38.64 \\
\hline Total & 44 & 100 \\
\hline
\end{tabular}

Left $:$ Right $=1.5: 1$ Table III shows distribution of patients according to side. Left side $27(61.36 \%)$ was more affected than right side17 (38.64\%). Left and right side ratio was 1.5: 1. 
Table-IV

Distribution of patients according to cortical thickness $(\mathrm{mm})(\mathrm{n}=44)$

\begin{tabular}{|c|c|c|c|}
\hline $\begin{array}{l}\text { Cortical thickness } \\
(\mathrm{mm})\end{array}$ & $\begin{array}{c}\operatorname{Mean}(\mathrm{mm}) \\
\pm \mathrm{SD}\end{array}$ & Range & $p$ value \\
\hline Pre operative & $3.67 \pm 0.91$ & $2.00-6.00$ & \\
\hline $\begin{array}{l}\text { Post operative after } \\
1 \text { month }\end{array}$ & $3.95 \pm 0.91$ & $2.50-6.00$ & 0.001 \\
\hline $\begin{array}{l}\text { Post operative after } \\
3 \text { months }\end{array}$ & $4.61 \pm 1.18$ & $2.50-7.50$ & 0.001 \\
\hline $\begin{array}{l}\text { Post operative after } \\
6 \text { months }\end{array}$ & $5.15 \pm 1.31$ & $2.50-7.50$ & 0.001 \\
\hline $\begin{array}{l}\text { Post operative after } \\
12 \text { months }\end{array}$ & $6.22 \pm 1.37$ & $2.50-8.00$ & 0.001 \\
\hline
\end{tabular}

Paired t- test

Table IV shows the distribution of patients according to cortical thickness. The mean \pm SD of pre operative thickness was $3.67 \mathrm{~mm} \pm 0.91 \mathrm{~mm}$ with a range of $2.00 \mathrm{~mm}-6.00 \mathrm{~mm}$. The mean \pm SD of post operative thickness after 1 month, 3 months, 6 months and 12 months were $3.95 \mathrm{~mm} \pm 0.91 \mathrm{~mm}, 4.61 \mathrm{~mm} \pm 1.18 \mathrm{~mm}$, $5.15 \mathrm{~mm} \pm 1.31 \mathrm{~mm}$ and $6.22 \mathrm{~mm} \pm 1.37 \mathrm{~mm}$ respectively. Improvement was seen in each follow up significant.

Table- $V$ shows the distribution of respondents according to isotope renogram. The mean \pm SD of split renal function were $24.22 \pm 3.42$ and $29.14 \pm 4.20$ in pre operative and post operative respectively. The mean \pm
Outcome of Open Pyeloplasty on Ipsilateral Renal Function

SD of split GFR were $25.38 \pm 4.11$ and $34.47 \pm 6.30$ in pre operative and post operative respectively.

Table-V

Distribution of patients according to Isotope renogram $(n=44)$

\begin{tabular}{lccc}
\hline Isotope renogram & Pre Mean \pm SD & Post Mean \pm SD & p value \\
\hline Split function (\%) & $24.22 \pm 3.42$ & $29.14 \pm 4.20$ & 0.001 \\
& $(15.90-29.90)$ & $(19.00-35.10)$ & \\
Split GFR (ml/min.) & $25.38 \pm 4.11$ & $34.47 \pm 6.30$ & 0.001 \\
& $(17.00-33.20)$ & $(16.00-42.60)$ & \\
\hline
\end{tabular}

Paired t- test

Table-VI

Distribution of patients according to renal functional outcome $(n=44)$

\begin{tabular}{lcc}
\hline Functional outcome & No & Percentage \\
\hline Improved & 39 & 88.63 \\
Stable & 3 & 6.82 \\
Deterioration & 2 & 4.55 \\
\hline Total & 44 & 100.0 \\
\hline
\end{tabular}

Table VI shows the distribution of patients according to renal functional outcome. Improved $39(88.63 \%)$ cases, stable $3(6.82 \%)$ cases, and deterioration 2 (4.55\%) cases.

Table-VII

Distribution of patients with age related improvement of renal function

\begin{tabular}{lccccc}
\hline Age group & $\begin{array}{c}\text { Improved } \\
\mathrm{n}(\%)\end{array}$ & $\begin{array}{c}\text { Pre split } \\
\text { renal function } \\
\text { mean } \pm \text { SD } \\
(\text { Range) }\end{array}$ & $\begin{array}{c}\text { Post split } \\
\text { renal function } \\
\text { mean } \pm \text { SD } \\
\text { (Range) }\end{array}$ & $\begin{array}{c}\text { Pre GFR } \\
\text { mean } \pm S D \\
\text { (Range) }\end{array}$ & $\begin{array}{c}\text { Post GFR } \\
\text { mean } \pm S D \\
\text { (Range) }\end{array}$ \\
\hline$\leq 5$ & $26(96.29)$ & $24.31 \pm 3.84$ & $30.16 \pm 3.78$ & $26.25 \pm 3.92$ & $36.38 \pm 3.87$ \\
$6-10$ & $(80.00)$ & $24.22 \pm 3.14$ & $28.62 \pm 3.37$ & $26.13 \pm 2.76$ & $35.31 \pm 5.19$ \\
& & $(19.00-29.00)$ & $(24.10-34.00)$ & $(21.00-30.10)$ & $(25.20-40.90)$ \\
$>10$ & $5(71.43)$ & $24.21 \pm 2.61$ & $27.15 \pm 5.62$ & $21.32 \pm 4.64$ & $27.71 \pm 9.56$ \\
& & $(21.00-29.00)$ & $(19.00-33.10)$ & $(17.00-30.00)$ & $(16.00-40.00)$ \\
\hline
\end{tabular}

Table VII shows the distribution of patients by age and improvement of renal function. It showed that 26(96.29\%) patients in age group $\leq 5$ years, $8(80 \%)$ patients in $6-10$ years age group and $5(71.43 \%)$ patients in age group $>10$ years had improved renal function. 


\section{Discussion}

Ureteropelvic junction obstruction is defined as an obstruction to the flow of urine from the renal pelvis to the proximal ureter. As a result of back pressure within the renal pelvis, progressive renal damage and deterioration sets in. Widespread use of ultrasonography and the advent of modern imaging techniques have resulted in earlier diagnosis of ureteropelvic junction obstruction. The condition is frequently encountered by both adult and pediatric urologists, and was more common in boys, as noted in the present study. In the present study, Male patients were 33(75\%) and female patients were $11(25 \%)$. The male and female ratio was 1: 0.33. Bansal reported male to female ratio 3:1[2].

The purpose of surgical intervention for hydronephrosis is to stabilize, improve renal function. Previously, nephrectomy was often performed on patients with unilateral hydronephrosis[5]. In the present study, the patients were separated into three groups d" 5 years, in which the number of patients were 27 (61.4\%), 6-10 years, in which the number of patients were 10 (22.7\%), and $>10$ years, in which the number of patients were 7 (15.9\%) respectively and functional improvement was more likely in the younger patients. Mean age was 7.89 years. Bansal et al. reported mean age of 8.6 years[2]. Kinn AC. reported that early pyeloplasty in 26 of 321 children with prenatally diagnosed ureteropelvic junction obstruction led to stabilize relative renal function but not to significantly improved function[6]. Renal function could be improved by a pyeloplasty procedure especially true in the case of younger patients[5].

In this study, left to right side ratio was 1.5:1. Left kidney was affected in $27(61.36 \%)$ patients. Right kidney was affected in 17 (38.64\%) patients. This result was comparable to other studies. Bansal R. et al. reported left to right side ratio was 1.3:1[2]. Sungchan Park et al. reported among 46 patients, 35 and 11 affected on left side and right side respectively[4].

Shokeir et. al. studied that ultrasonography was a great help in evaluating the degree of obstructive renal damage, through assessment of the thickness of the renal parenchyma (measuring length and width of kidney and dimensions of renal pelvis)[7]. In this study, cortical thickness measured by ultrasound by different operator. Thus measurement of cortical thickness may have inherent bias. In the present study, the mean of preoperative cortical thickness of affected kidney measured by ultrasound was $3.67 \mathrm{~mm}$. The mean of postoperative renal cortical thickness after 1 month, 3 months, 6 months and 12 months of pyeloplasty were $3.95 \mathrm{~mm}, 4.61 \mathrm{~mm}, 5.15 \mathrm{~mm}$ and $6.22 \mathrm{~mm}$ respectively. Improvement was seen in each follow up was significant $(P=0.001)$. Two patients had same cortical thickness before and after pyeloplasty. Two patients had decreased cortical thickness. Provided that there is no renal medical disease, the greater the thickness of the renal parenchyma, the better the recovery of renal function after the relief of obstruction[8].

In the present study preoperative mean split renal function was $24.22 \% \pm 3.42 \%$ (mean \pm SD) (range $15.90 \%$ $29.90 \%$ ). Postoperative mean split renal function was $29.14 \pm 4.20$ (mean \pm SD) (range $19.00-35.10)$. The improvement was significant $(P=0.001)$. The average change in split renal function was $20 \%$. Three patients had same split renal function both pre and post operatively. The split renal function was $21.9 \%, 24.1 \%$, and $27.2 \%$ in three patients respectively. The reason may be due to failure of growth of renal tissue which was evident by same cortical thickness of kidney on ultrasonography. Two patients had deterioration of split renal function post operatively. Of this two, pre operative split renal function was $25 \%$ and $22 \%$ respectively; post operative split renal function was $21 \%$ and $19 \%$ respectively. The cause may be due to presence of very little renal cortical tissue as both patients age was 36 and 37 years respectively. O'Reilly PH reported that among 24 patients 19 (79\%) patients had improved split renal function; the median improvement was from $32 \%$ to $43.5 \%(P=0.005)$. Twenty-three patients $(96 \%)$ had improved drainage on diuretic renography[9]. Fourteen children aged 3 months to 16 years undergoing pyeloplasty, using ${ }^{99 m}$ Tc-DMSA renography, and showed an increase in split renal function at 3-44 months of follow up[10].

Bansal et al. studied the natural history of ureteropelvic junction obstruction; while some cases undergo progressive or irreversible renal damage, others remain stable for long periods or even improve with growth. When the number of functioning nephron decreases, there is an increase in the single nephron filtration rate. This adaptive response, called glomerular hyperfiltration, contributes to the maintenance of homeostasis. This represents the ability of the kidney to increase the glomerular filtration rate (GFR)[2]. In the present study, preoperative mean of split glomerular filtration rate (GFR) increased from $25.38 \pm 4.11 \mathrm{ml} / \mathrm{min}$ to $34.47 \pm 6.30 \mathrm{ml} /$ min that was post operative mean of split glomerular filtration rate in 39 patients. Three patients had same 
glomerular filtration rate both pre and post operatively. Two patients developed reduced split glomerular filtration rate (GFR) postoperatively. The reason may be due to reduced pre existing renal cortical tissue as their age was higher. Morsi HA et. al. reported that improvement of glomerular rate from $31.3 \pm 18.50$ to $38.1 \pm 23.23 \mathrm{ml} /$ $\min$ [11].

In the present study, among 44 patients 39(88.63\%) patients had improved renal function. Among 39 patients $26(96.29 \%)$ patients were in the age group $<5$ years, $8(80 \%)$ patients were in the age group $6-10$ years and $5(71.43 \%)$ patients were in the age group $>10$ years had improved renal function. Mean preoperative split renal function was $24.31 \pm 3.84 \%$ and mean postoperative split renal function was $30.16 \pm 3.78 \%$ in the $<5$ years age group. Mean preoperative glomerular filtration rate was $26.25 \pm 3.92 \mathrm{ml} / \mathrm{min}$ and mean postoperative glomerular filtration rate was $36.38 \pm 3.87$ in the $<5$ years age group.

Mean preoperative split renal function was $24.22 \pm 3.14 \%$ and mean postoperative split renal function was $28.62 \pm 3.37 \%$ in the $6-10$ years age group. Mean preoperative glomerular filtration rate was $26.13 \pm 2.76$ $\mathrm{mi} / \mathrm{min}$ and mean postoperative glomerular filtration rate was $35.31 \pm 5.19 \mathrm{ml} / \mathrm{min}$ in the $6-10$ year age group. Mean preoperative split renal function was $24.21 \pm 2.61 \%$ and mean postoperative split renal function was $27.15 \pm 5.62 \%$ in the $>10$ year age group. Mean preoperative glomerular filtration rate was $21.32 \pm 4.64 \mathrm{ml} / \mathrm{min}$ and mean postoperative glomerular filtration rate was $27.71 \pm 9.56$ $\mathrm{ml} / \mathrm{min}$. Three patients (6.82\%) had stable, and 2(4.55\%) patients had deteriorated renal function in terms of increased split renal function and glomerular filtration rate on isotope renogram. Moreira-Pinto et al. reported that improved renal function in $89 \%$, stable in $7 \%$, and deterioration in $4 \%$ of patients which was comparable to this study[12].

\section{Conclusions}

It was concluded that when dealing with patients with pelviureteric junction obstruction, surgical treatment of hydronephrosis should be undertaken in patients with symptoms and/or impaired renal function. As shown in the present study, renography carried out 12 months postoperatively revealed normal drainage and improved or stable renal function.

Younger age group showed better improvement of renal function than older age group.

\section{Conflict of Interest : None Declared}

\section{Referenes}

1. Arun N, Kekre NS, Nath V, Gopalakrishnan G. Is open pyeloplasty still justified? Br J Urol. 1997; 80: 379-381.

2. Bansal R, Ansari MS, Srivastava A, Kapoor R. Long - term results of pyeloplasty in poorly functioning kidneys in the pediatric age group. J Pediatr Urol. 2012; 8: 25-28.

3. Carr MC. Annomalies and surgery of the ureteropelvic junction in children. In: Kavoussi LR, Novick AC, Partin AW, Peters CA, editors. Campbell - Walsh urology. Philadelphia: W. B. Saunders; 2010. p. 3359-3382.

4. Park S, Ji HY, Park KH, Han DH, Kim KS. Difference in results of ultrasonography and diuretic renograms after pyeloplasty in children with unilateral ureteropelvic junction obstruction. Kor J Urol. 2009; 50: 596-601.

5. Poulsen EU, Jørgensen TM, Jensen FT, Djurhuus JC. The functional outcome of Anderson - Hynes pyeloplasty for hydronephrosis. Scnad J Urol Nephrol. 1987; 21:213-217.

6. Kinn AC. Ureteropelvic junction obstruction: long - term follow up of adults with and without surgical treatment. J Urol. 2000; 164: $652-656$.

7. Shokeir AA, Provoost AP, Nijman RJM. Recoverability of renal function after relief of chronic partial upper urinary tract obstruction. BJU International, 1999; 83: 11-17.

8. Davari HA, Haghighi M, Shahi Z, Azar MH. Improvement of renal function after relief of chronic partial upper urinary tract obstruction. JRMS. 2005;10: 74-76.

9. O'Reilly PH, Brooman PJC, Mak S, Jones M, Pickup C, Atkinson C. et al The long-term results of Anderson-Hynes pyeloplasty. BJU International. 2001; 87: 287-289.

10. Ortapamuk H, Naldoken S, Tekdogan UY, Aslan $Y$, Atan A. Differential renal function in the prediction of recovery in adult obstructed kidneys after pyeloplasty. Ann Nucl Med. 2003; 17: 663-668.

11. Morsi HA, Mursi K, Abdelaziz AY, Salah EM, Eissa M. Renal pelvis reduction during dismembered pyeloplasty: Is it necessary? J Pediatr urol. 2012; 20: 1-4.

12. Moreira-Pinto J, Osório A, Vila F, de Castro JLR, Réis A. Dismembered pyeloplasty for ureteropelvic junction syndrome treatment in children. Afr J Pediatr Surg. 2012; 9: 98-101.

Abbreviations:

GFR : Glumerular Filtration Rate 